\title{
Growth of green mussel (Perna viridis L.) culture at two different depths in estuary waters of Alue Naga Village, Banda Aceh
}

\author{
Dedi Fazriansyah Putra ${ }^{1 *}$, Akmal Rizqullah ${ }^{1}$, Adli Waliul Perdana ${ }^{1}$ \\ ${ }^{1}$ Department of Aquaculture, Faculty of Marine and Fisheries, Universitas Syiah Kuala, Aceh, Indonesia. \\ Jl. Teuku Nyak Arief No.441, Kopelma Darussalam, Kec. Syiah Kuala, Kota Banda Aceh, Aceh. 23111
}

\begin{abstract}
Green mussel (Perna viridis L.) is one of economically valuable shellfish that can be potentially developed to support the people economic income. This study aimed to investigate the growth performance of green mussels at two different groups. Two groups of 15-individual green mussels' culture was cultured repeatedly forthree times.. The two groups treatment used were $0.9 \mathrm{~m}$ depth and on the surface of the water. TThe growth performances were quantified in terms ofweight gain, length gain, daily growth rate, daily length growth rate, specific growth rate, specific length rate. Result showed that green mussels with a depth of $0.9 \mathrm{~m}$ and water surface were weight gain, length gain, daily growth rate, daily length growth rate, specific growth rate, specific length rate by values of $10.33 \pm 0.43 \mathrm{~g}, 38.12 \pm 2.02 \mathrm{~mm}, 0.11 \pm 0.004 \mathrm{gr} /$ day, $0.39 \pm 0.02 \mathrm{~mm} /$ day, $1.60 \pm 0.11 \%$ /day, and $0.80 \pm 0.02 \%$ /day and $8.09 \pm 0.21 \mathrm{~g}, 33.66 \pm 0.92 \mathrm{~mm}, 0.08 \pm 0.002 \mathrm{~g} /$ day, $0,34 \pm 0.01$, $1.27 \pm 0.03 \%$ /day and $0.74 \pm 0.02 \%$ /day, respectively. The growth performance of $0.9 \mathrm{~m}$ depth culture were significantly better that water surface culture. Therefore, it is concluded that the $0.9 \mathrm{~m}$ of green mussel culture is suggested to obtain the better growth performance.
\end{abstract}

\section{Introduction}

Mussels are belong to one of fisheries product that can be found in tropical regions and are a source of animal protein and have an economic price among the people. According the Ministry data [1], the production of aquaculture since 2014 to 2018 increased by $3,36 \%$ a year, one of its product, shellfish that reached a production of 1 million tons a year. Green mussel (Perna viridis, Linnaeus. 1758) is known as one of the popular seafood that contribute the significant economical income for Indonesian people that can be found from Sumatera, Jawa, Kalimantan, Bali, and Sulawesi [2].

The estuaria of Alue Naga is one of the biggest coastal area located in the city of Banda Aceh. It is near to the community settlement, so it's very efficient to be managed and has a potential to improve people's economies. Nowadays, the Alue Naga reservoir is used by surrounding villagers as a location for fishing and marine cultivation such as oysters and green mussel.

Green mussels can be found everywhere around the Alue Naga estuaries but they are very few in number. It should be noted that local people take green mussels in all sizes, both small and large sizes. Small green mussels will be cultivated first, and will be harvested within the next 3 or 4 months. Most of the people of Alue Naga Village cultivate green mussels on the surface of the waters, but there are also those who cultivate close to the bottom of the water. Green mussels can be harvested when they are 6-9 cm length [3].

The people of Alue Naga village catch green mussels when the water conditions at low tide, and slow current. The difficulty of getting the right momentum to catch green mussels makes the fishermen take all sizes of green mussles without grade selection. According to research conducted by various authors, the morphometcric characteristics of green mussels contribute as an important reference for monitoring and evaluating the growth and condition of species, especially in natural populations in cultivated or wild environments [4].

Growth is defined as an increase in size, both lenght and weight. Growth is influenced by genetic, hormonal, and environmental factors (nutrients). These three factors work to influence each other, both in the sense of mutually supporting and interfering with each other to control developments that will occur [4]. The growth performance of green mussels in different depth in Banda Aceh coastal area has not been explored yet. Therefore, the aim of this research is to investigate the growth performance of green mussels at different depths.

* Corresponding author: dfputra@unsyiah.ac.id 


\section{Research Methods}

\subsection{Place and Time}

This research was conducted for fourteen weeks starting from October to December 2020 at the estuary waters of Alue Naga Village, Syiah Kuala District, Banda Aceh City, Aceh Province. Measurement of the weight and length of green mussels has been carried out directly at the cultivation site.

\subsection{Research Procedure}

\subsubsection{Catching green mussels}

The capture of mussel samples was carried out using hands and a knife as a tool to separate the green mussels from the substrate. The green mussels samples taken were as many as 90 ind.

\subsubsection{Experimental design}

Two different depth of green mussels' culture were repeated three times with 15 individuals each. The depth treatment used were $0.9 \mathrm{~m}$ depth and on the surface of the water as shown in figure 2 .

\subsubsection{Research container}

The green mussels that have been obtained then put into six baskets that have been prepared, each basket used has a square shape with a size of $(30 \times 50) \mathrm{cm}$, which has been lined with nets with the intention that shells that are too small will not fall or disappear from the container. Stuffed with 15 green mussels. This study used step on the chart in one column the same waters, a total of 3 containers has been tied to the rafters at the depth of 0.9 meters and 3 containers has been again tied on the surface of the waters.

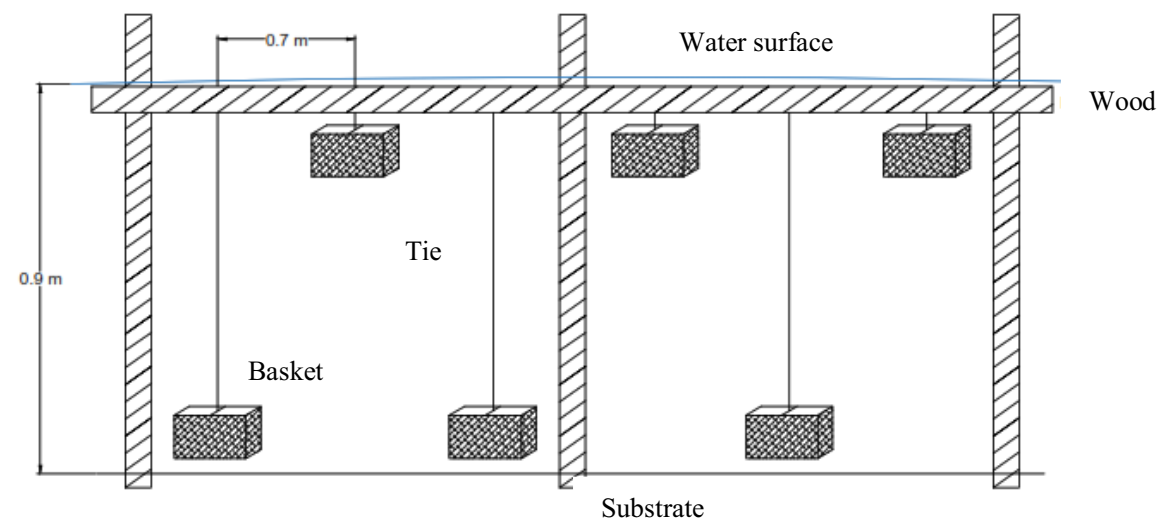

Figure 2. Illustration of a cultivation container

\subsubsection{Measurement of length and weight}

Measurements of the length and weight of mussels were carried out directly at the location of cultivation. In measuring the length of the shell, the tool used was a digital caliper ( $1 \mathrm{~mm}$ accuracy). Meanwhile, in measuring the total weight of shellfish, the tool used was a digital scale in grams with an accuracy of 0.1 grams.

\subsection{Data analysis}

\subsubsection{Absolute weight gain}

The absolute weight gain is the difference between the total weight at the end and the beginning of maintenance. Absolute weight growth can be calculated using the following formula [5]:

$$
\mathrm{Wm}=\mathrm{Wt}-\mathrm{Wo}
$$

Information :

$\mathrm{Wm}=$ Absolute weight gain (gr)

$\mathrm{Wt}=$ Average weight at the end of the study (gr)

Wo = Average weight at the beginning of the study (gr)

\subsubsection{Absolute Length Gain}

The absolute length gain is the difference between the total length at the end and the beginning of the rearing. Absolute length growth can be calculated using the following formula [4]:

$$
\mathrm{Lm}=\mathrm{Lt}-\mathrm{Lo}
$$

Information :

$\mathrm{Lm}=$ Absolute length gain $(\mathrm{mm})$

$\mathrm{Lt}=$ Average length at the end of the study $(\mathrm{mm})$

Lo = Average length at the beginning of the study ( $\mathrm{mm})$ 


\subsubsection{Daily Weight Rate/DWR}

The daily weight rate was calculated using the following formula [6]:

$$
\operatorname{DGR}(\mathrm{W})=\frac{\mathrm{Wm}}{\mathrm{t}}
$$

Information :

$$
\begin{array}{ll}
\mathrm{DGR}(\mathrm{W}) & =\text { Daily weight growth rate }(\mathrm{gr} / \text { day }) \\
\mathrm{Wm} & =\text { Total weight gain }(\text { gr) } \\
\mathrm{t} & =\text { Maintenance time }(\text { day })
\end{array}
$$

\subsubsection{Daily Length Rate/DLR}

The daily length rate was calculated using the following formula [6]:

$$
\operatorname{DGR}(\mathrm{L})=\frac{\mathrm{Lm}}{\mathrm{t}}
$$

Information :

DGR $(\mathrm{L})=$ Daily weight growth rate $(\mathrm{mm} /$ day $)$

$\mathrm{Lm}=$ Absolute lenght gain $(\mathrm{mm})$

$\mathrm{t} \quad=$ Maintenance time (day)

\subsubsection{Spesific Weight Growth Rate/SGR}

Spesific Weight Growth Rate (SGR \%/day) of the weight (SGR G) of green mussels, which was calculated according to [7] as follows:

$$
\begin{aligned}
\mathrm{SGR}(\mathrm{W})=\frac{\text { LnWt }- \text { LnW0 } 0}{t} & \times 100 \% \\
\text { Information } \quad: \mathrm{W}_{0} & =\text { Initial weight }(\mathrm{gr}) \\
\mathrm{W}_{\mathrm{t}} & =\text { Final weight }(\mathrm{gr}) \\
\mathrm{t} & =\text { Length of cultivation of }
\end{aligned}
$$

green mussels

\subsubsection{Spesific Length Growth Rate/SGR}

Spesific Length Growth Rate (SGR \%/day) of the length (SGR L) of green mussels, which was calculated as $[8,9]$ :

SGR $(L)=\frac{\text { LnLt }- \text { LnL0 }}{t} \times 100 \%$

Information: $\mathrm{L}_{0} \quad=$ Initial length $(\mathrm{mm})$

$$
\mathrm{L}_{\mathrm{t}} \quad=\text { Final length }(\mathrm{mm})
$$

$\mathrm{t}=$ Length of cultivation of green mussels

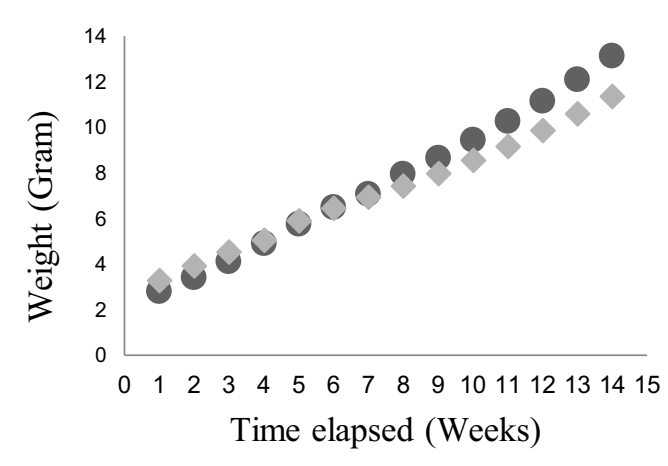

\subsubsection{Survival Rate (SR)}

Survival rate (SR) is calculated based on the following formula [7]:

$\mathrm{SR}=\frac{\text { No }-\mathrm{Nt}}{\mathrm{No}} \times 100 \%$

Information:

$\mathrm{SR}=$ Survival rate $(\%)$

$\mathrm{Nt}=$ Total of shrimp at the end of the study (tails)

No $=$ Total of shrimp at the beginning of the study (tails)

\subsection{Data analysis}

Data analysis of the effect of treatment on research parameters using the Independent samples T-test.. Basis for decision making test Independent samples T-test with $95 \%$ confidence level . If the value is significant (2-tailed) $>\mathrm{p}$-value (0.05), then accept $\mathrm{H} 0$ and reject $\mathrm{H} 1$. If the value is Significant (2-tailed) $<$ p-value $(0.05)$, then reject $\mathrm{H}_{0}$ and accept $\mathrm{H}_{1}$.

Hypothesis:

$\mathrm{H}_{0}=$ The growth of treatment A and treatment B was not significantly different.

$\mathrm{H}_{1}=$ The growth of treatment A with treatment B there is a significant difference

\section{Results and Discussions}

The results showed that the absolute weight gain during the fourteen weeks of the study period in treatment (A) with a depth of 0.9 meters on average was $10.33 \pm 0.43$ grams, and in treatment (B) or on the surface an average of $8.09 \pm 0.21$ grams. While in treatment (A) with a depth of 0.9 meters the average absolute length increase was about $38.12 \pm 2.02 \mathrm{~mm}$, and in treatment (B) the average was about $33.66 \pm 0.92 \mathrm{~mm}$. These results can be seen that the cultivation treatment with different depths has an effect on the speed of growth, the treatment located at a depth of 0.9 meters experienced faster growth (figure 3).

Fig.3. Weight and length growth trend (Treatment A)

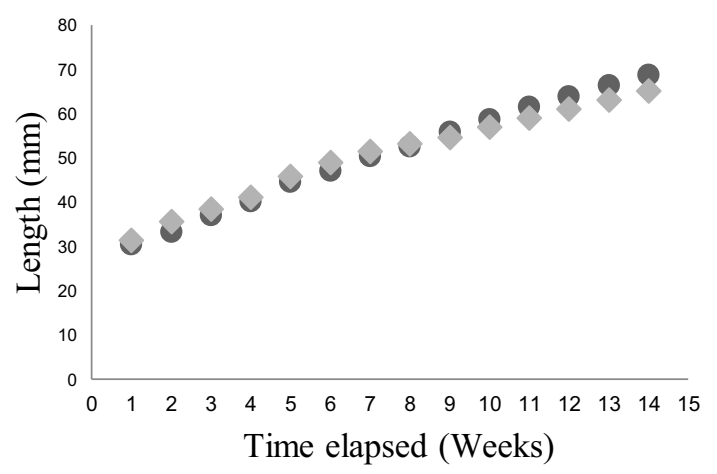


The results of research on the growth of green mussels have been presented in table 1 as follows:

Tabel 1. The measurement results of research parameters

\begin{tabular}{|c|c|c|c|c|c|c|c|}
\hline Treatment & $\begin{array}{c}\text { Wm } \\
(\mathrm{gr})\end{array}$ & $\begin{array}{c}\text { Lm } \\
(\mathrm{mm})\end{array}$ & $\begin{array}{c}\text { DGR (W) } \\
(\mathrm{gr} / \text { day })\end{array}$ & $\begin{array}{c}\text { DGR (L) } \\
(\mathrm{mm} / \text { day })\end{array}$ & $\begin{array}{c}\text { SGR (W) } \\
(\% / \text { day })\end{array}$ & $\begin{array}{c}\text { SGR (L) } \\
(\% / \text { day })\end{array}$ & $\begin{array}{c}\text { SR } \\
(\%)\end{array}$ \\
\hline Treatment (A) & $10,33 \pm 0,43$ & $38,12 \pm 2,02$ & $0,11 \pm 0,004$ & $0,39 \pm 0,02$ & $1,60 \pm 0,11$ & $0,80 \pm 0,02$ & 100 \\
\hline Treatment (B) & $8,09 \pm 0,21$ & $33,66 \pm 0,92$ & $0,08 \pm 0,002$ & $0,34 \pm 0,01$ & $1,27 \pm 0,03$ & $0,74 \pm 0,02$ & 100 \\
\hline
\end{tabular}

The growth rate of daily weight at a depth of 0,9 meters averaging $0.11 \pm 0.004$ grams/day, and daily weight growth rate in surface waters by an average of $0.08 \pm 0.002$ gram/day. The average daily length growth rate at a depth of 0.9 meters was $0.39 \pm 0.02 \mathrm{~mm} /$ day, and the daily length growth rate at the surface of the waters averaged $0.34 \pm 0.01 \mathrm{~mm} /$ day. The growth rate of a specific weight at a depth of 0,9 meters averaging of $1.60 \pm 0.11 \%$ /day, and the rate of postpartum harbor waters specific gravity on the surface an average of $1.27 \pm 0.03 \%$ /day. The growth rate of a specific length at a depth of 0,9 meters averaging of $0.80 \pm 0.02 \% /$ day, and the rate of growth of a specific length on surface waters by an average of $0.74 \pm$ $0.02 \% /$ day.

The treatment of green mussel cultivation for fourteen weeks which experienced the best weight and length gain was found in treatment (A) with an absolute weight gain of $10.33 \pm 0.43 \mathrm{~g}$, and an absolute length increase of 38.12 $\pm 2.02 \mathrm{~mm}$. The daily weight growth rate was $0.11 \pm 0.004$ $\mathrm{g} /$ day, and the daily length growth rate was $0.39 \pm 0.02$ $\mathrm{mm} /$ day. The specific weight growth rate was $1.60 \pm 0.11 \% /$ day, the specific length growth rate was $0.80 \pm 0.02 \%$ /day, and the survival rate (SR) was $100 \%$. This is different from the results of the study of [10], green mussel cultivation carried out for 60 days with different stocking densities with a depth of 1.5 meters showed the best weight and length gain with 20 individuals with a specific weight growth rate of $1.18 \pm 0.04 \%$ /day and the specific length growth rate was $0.86 \pm 0.01 \%$ /day.

The final weight at the fourteenth week of the results of this study had an average weight of all green mussels ranging from $12.22 \pm 1.11 \mathrm{~g} /$ head with an average length of
$66.87 \pm 2.53 \mathrm{~mm}$. This is in accordance with the results of research by [3] which states that the maximum length of green mussels can reach more than $10 \mathrm{~cm}$. The increase in length from this study has an average length of $2.5 \mathrm{~mm}$ per week or $1 \mathrm{~cm}$ per month. This is reinforced by the results of research [11] namely the effect of different types of rope on the level of attachment of green mussel seeds to obtain optimal results the best average length of green mussels on natural fibers with a length of $0.5-1 \mathrm{~cm}$ in a month. This is reinforced by the results of the research by [3] that green mussels can grow between 0.5 to $0.9 \mathrm{~cm}$ in a month, but there is an abnormal growth rate with a growth speed of $1.5 \mathrm{~cm}$ in a month against the moon. third and fourth from the beginning of cultivation, and the size of green mussels ready for harvest ranged from 6 to $9 \mathrm{~cm}$. This is different from the results of Andriyani [12], the growth rate of green mussels with a depth of $3 \mathrm{~m}, 5 \mathrm{~m}$, and $10 \mathrm{~m}$ cultivated offshore, the best results were obtained at a depth of 5 meters with an increase in length of $1.3 \mathrm{~cm}$ in a month. while at a depth of $3 \mathrm{~m}$ and $10 \mathrm{~m}$ each experienced an increase in length of $1 \mathrm{~cm}$ in a month.

The deeper the waters, the less light that enters the waters, so this can also be a different factor in the growth speed of the green mussels. This study shows that on the surface of the waters green mussels grow slower than those at a depth of 0.9 meters. This is also supported by the statement of [13], so that the shells of clams are more open and the food filtering process can maximize the shellfish both in waters where the light intensity is not too high, but if the waters are too deep it can result in waves that are too big.

Tabel 2. Water quality parameters data

\begin{tabular}{|c|c|c|c|}
\hline No & Water Quality Parameters & Unit & Measurement results \\
\hline 1 & Current & $\mathrm{m} / \mathrm{s}$ & 17 \\
\hline 2 & Brightness & Meter & 0,7 \\
\hline 3 & Salinity & Ppt & 31 \\
\hline 4 & Depth & Meter & Low tide $=0,9$ \\
& & & High tide $=1,7$ \\
\hline 5 & $\mathrm{pH}$ & - & 8,7 \\
\hline 6 & Temperature & $\mathrm{Cg} / \mathrm{L}$ & 29 \\
\hline 7 & Dissolved Oxygen & & 4,8 \\
\hline
\end{tabular}


One of the water quality parameters used was brightness, the brightness is determined visually to measure the transparency in a waters, the tool used is a sechi disk. The unit used to measure brightness is the meter. Brightness was measured in this study is 0,9 meters with sandy mud waters substrate condition. This brightness level is also due to the condition of the waters, the presence of rivers and run-off from land which empties into the research location so that it can affect the brightness of the waters. This is reinforced by the results of research by [14], the level of turbidity in waters is influenced by organic and inorganic materials, dissolved particles, and the amount of sediment supply through run-off flows from the mainland.

One of the parameters that determine the ecosystem of an aquatic ecosystem is dissolved oxygen (DO). Measurement of dissolved oxygen content in the farming area of green mussels are $4.8 \mathrm{mg} / \mathrm{L}$. According to water quality standards from the [15], marine biota is $>5 \mathrm{mg} / \mathrm{l}$ for the survival of biota and for optimal development. According to [16], this is due to the small number of aquatic plants that act as the largest oxygen supplier in growing waters.

Factors that also affect the survival of green mussels are temperature, high temperatures will have an impact on growth and survival. The result of the measurement of the temperature parameter is $29^{\circ} \mathrm{C}$. According to [5], a good place for green mussel cultivation is waters that have a natural temperature ranging from $23-32^{\circ} \mathrm{C}$.

According to [17], the $\mathrm{pH}$ of the waters greatly affects the life of the biota that live in these waters, changes in the $\mathrm{pH}$ itself can affect the activity and growth of these biota, because a $\mathrm{pH}$ that tends to be acidic will have a low DO. The results of measuring $\mathrm{pH}$ using a pH meter in this study were 8.7 and still classified as good for the growth of green mussels. The $\mathrm{pH}$ of the waters that are suitable and suitable for use as a place for cultivating green mussels are waters that have a $\mathrm{pH}$ ranging from 6.5 to 9 [17].

An important factor that affects the success of marine cultivation, one of which is green mussels is salinity. The measurement results show that the salinity in the waters of the study area is around $31 \mathrm{ppt}$. The salinity at the location of this study is classified as good for green mussel cultivation, this is supported by the statement of [18] which states that, for the selected location for green mussel cultivation, the salinity is classified as suitable between 27-32 ppt.

\section{Conclusions}

The test results Independent samples t-test to the p rowth green mussel treatment (A) into an $0.9 \mathrm{~m}$ by treatment (B) in the surface waters significantly affect weight gain, the length, the growth rate of daily weight, daily length growth rate, the rate of specific weight growth and specific length growth rate. Treatment (A) with a depth of 0.9 meters was the best with a final weight gain of $10.33 \pm 0.43 \mathrm{~g}$, and a final length increase of $38.12 \pm$ $2.02 \mathrm{~mm}$. The daily weight growth rate was $0.11 \pm 0.004$ $\mathrm{g} /$ day, and the daily length growth rate was $0.39 \pm 0.02$ $\mathrm{mm} /$ day. The growth rate of the specific weight of 1.60 $\pm 0.11 \% /$ day, and the rate of growth of a specific length of $0.80 \pm 0.02 \% /$ day.

\section{References}

1. KKP, Laporan Tahunan Kementerian Kelautan dan Perikanan (2018)

2. H.A.W. Cappenberg, Oseana, 33, 1 (2008)

3. Yonvitner, S. Sukimin, J. Ilm. Pendidik Biol. (Biologi Edukasi), 1, 2 (2009)

4. S.M. Aban, F. Albert, T. Argente, R.S. Raguindin, A.C. Garcia, C.E. Ibarra, PSU J .Nat Allied. Sci, 1, 1 (2017)

5. H. Effendi, Telaah Kualitas Air Bagi Pengelolaan Sumber Daya Dan Lingkungan Perairan (2003)

6. I. Rusydi, I. Dewiyanti, M. Maisuri, D.F. Putra, C. Octavina, N. Nurfadillah, IOP Conf. Ser. Earth Environ. Sci, 1 (2021)

7. D.F. Putra, M. Muhsinah, I.I. Arisa, IOP Conf. Ser. Earth Environ. Sci, 1 (2021)

8. K.D. Hopkins, Reporting Fish Growth: A Review of the Basics, J. World Aquac. Soc, 23, 3 (1992)

9. G. Naik, M.G.G. Aziz. M, V. Ambily, S.B.B. Nandan, J.V. Thomas, B.M. Kurup, India, Indian J. Fish, 5, 2 (2013)

10. A. Sagita, R. Kurnia, S. Sulistiono, J Ris. Akuakultur, 12, 1 (2017)

11. Sulvina, N.M. Noor, H, Wijayanti, S. Hudaidah, eJurnal Rekayasa dan Teknol. Budid. Perair. 4, 1 (2015)

12. S. Andriyani, Undergraduate thesis, UIN Sunan Ampel Surabaya (2019)

13. I.G.Y. Wisnawa, JST, Jurnal Sains dan Teknol, 2, 2 (2014)

14. B. Hamuna, R.H.R. Tanjung, S. Suwito, H.K. Maury, A. Alianto, J Ilmu Lingkung, 16, 1 (2018)

15. Menteri Lingkungan Hidup RI, Keputusan Menteri Lingkungan Hidup No 51 Tahun 2004 Tentang Baku Mutu Air Laut, Lembaran Negara Republik Indonesia, 51 (2004)

16. M. Ali, H.W. Maharani, S. Hudaidah, H. Fornando, Mispari J, 7, 2 (2015)

17. J.S.S. Hikmah, H.L. Ika, Res. J. Life Sci, 2, 1 (2015)

18. TPW. Indonesia, Budidaya Kerang Hijau (Perna viridis) (2015) 